\title{
Management tools in nursing care for children with pressure injury
}

\author{
Ferramentas gerenciais no cuidado de enfermagem a criança com lesão por pressão \\ Herramientas de gestión em atención de enfermería para niños con lesión de presión
}

\section{Carla Braga Oliveira Rodrigues' ORCID: 0000-0002-9659-9040}

Thiago Nascimento do Prado" ORCID: 0000-0001-8132-6288

Luciana de Cássia Nunes Nascimento" ORCID: 0000-0003-4947-5480

Mariana Rabello Laignier" ORCID: 0000-0002-8493-872X

Cândida Caniçali Primo" ORCID: 0000-0001-5141-2898

Maria Edla de Oliveira Bringuente" ORCID: 0000-0002-5151-5368

'Hospital Estadual Infantil Nossa Senhora da Glória. Vitória, Espírito Santo, Brazil. "Universidade Federal do Espírito Santo. Vitória, Espirito Santo, Brazil.

How to cite this article: Rodrigues CBO, Prado TN, Nascimento LCN Laignier MR, Primo CC, Bringuente MEO. Management tools in nursing care for children with pressure injury. Rev Bras Enferm. 2020;73(Suppl 4):e20180999. doi: http://dx.doi.org/10.1590/0034-7167-2018-0999

\section{Corresponding author:}

Carla Braga Oliveira Rodrigues E-mail: carlaenfermagem@yahoo.com.br

EDITOR IN CHIEF: Antonio José de Almeida Filho ASSOCIATE EDITOR: Fátima Helena Espírito Santo

\section{ABSTRACT}

Objectives: to develop and validate management tools for the systematization of nursing care for children with pressure injuries. Methods: methodological study in which the focus group technique was used for validation of tools in three different groups of 17 nurses. Conducted in April and May 2018 at a large pediatric hospital. Results: two management tools were developed. The first was the Nursing care systematization instrument for children with pressure injury with three parts: a) risk factors; b) Psychobiological Basic Human Needs; c) signs of wound infection. The second was the Flowchart of pressure injury risk and prevention in pediatric patients with three categories: a) risk factors; b) Braden $\mathrm{Q}$ scale; c) nursing care. Final Considerations: the tools will support nurses in the care of children with pressure injuries by aiming at an individualized and systematized assessment based on a theoretical framework.

Descriptors: Pressure Injury; Nursing Care; Pediatrics; Nursing Process; Pediatric Nursing.

\section{RESUMO}

Objetivos: elaborar e validar ferramentas gerenciais para sistematização do cuidado de enfermagem à criança com lesão por pressão. Métodos: estudo metodológico com uso da técnica de grupo focal em três diferentes grupos de 17 enfermeiros para validação das ferramentas. Realizado em abril e maio de 2018 em hospital pediátrico de grande porte. Resultados: duas ferramentas gerenciais foram elaboradas. A primeira foi o Instrumento de sistematização do cuidado de enfermagem à criança com lesão por pressão com três partes: a) fatores de risco; $b$ ) Necessidades Humanas Básicas Psicobiológicas; c) sinais de infecção da ferida. A segunda foi o Fluxograma de risco e prevenção de lesão por pressão em pacientes pediátricos com três categorias: a) fatores de risco; b) escala de Braden Q; c) cuidados de enfermagem. Considerações Finais: as ferramentas subsidiarão o enfermeiro no cuidado à criança com lesão por pressão visando avaliação individualizada, sistematizada e baseada em um referencial teórico.

Descritores: Lesão por Pressão; Cuidados de Enfermagem; Pediatria; Processo de Enfermagem; Enfermagem Pediátrica.

\section{RESUMEN}

Objetivos: desarrollar y validar herramientas de gestión para sistematizar la atención de enfermería para niños con lesión por presión. Métodos: investigación metodológica en que la técnica del grupo focal fue utilizada en tres grupos diferentes de 17 enfermeras para validar los instrumentos. Realizada en abril y mayo de 2018 en un gran hospital pediátrico. Resultados: se elaboraron dos herramientas de gestión. La primera fue el Instrumento de sistematización de la atención de enfermería para niños con lesión por presión con tres partes: a) factores de riesgo; b) Necesidades humanas básicas psicobiológicas; c) signos de infección de la herida. La segunda fue el diagrama de flujo de riesgo y prevención de lesión por presión en pacientes pediátricos con tres categorías: a) factores de riesgo; b) escala Braden Q; c) cuidados de enfermería. Consideraciones Finales: las herramientas ayudarán los enfermeros en el cuidado de niños con lesión por presión con el objetivo de una evaluación individualizada, sistematizada y basada en un marco teórico.

Descriptores: Lesión por Presión; Atención de Enfermería; Pediatría; Proceso de enfermería; Enfermería Pediátrica. 


\section{INTRODUCTION}

During hospitalization, children experience invasive and painful procedures and hospital restrictions that influence the stages of their development. The pressure injury (PI) is an adverse event to institutionalization and a health problem that prolongs hospitalization and suffering, and maintains a high incidence of complications such as infections and trauma, even with technological and scientific advances ${ }^{(1)}$.

In an effort to reduce the incidence of pressure injuries in individuals at risk, international guidelines recommend a thorough skin assessment within a maximum of eight hours after hospital admission ${ }^{(2)}$.

The use of a systematized instrument can reduce nurses' uncertainties, qualify the care provided, organize preventive behaviors, and allow the evaluation of results achieved with nursing care for clinical patients at risk of pressure injury in the hospital context ${ }^{(3)}$. Despite the importance of using a standardized pressure injury instrument, nurses' clinical judgment plays a major role in injury assessment ${ }^{(2)}$.

It is important to use instruments based on empirical indicators (observed or measured manifestations), on the basic human needs affected in children with pressure injury (theoretical framework of Wanda de Aguiar Horta's theory), and based on risk factors and signs of wound infection ${ }^{(4-5)}$.

From this perspective, emerged the question: does the use of management tools contribute to the safety process in the prevention of $\mathrm{PI}$ in pediatric patients?

\section{OBJECTIVES}

To develop and validate management tools for the systematization of nursing care for children with pressure injuries.

\section{METHODS}

\section{Ethical aspects}

The study followed the ethical requirements and was approved by the Research Ethics Committee of the Universidade Federal do Espírito Santo under number CAAE 77825317.4.0000.5071.

\section{Type of study}

This is a methodological study consisting of two moments: development of the instrument and content validation by nurses.

\section{Study scenario}

The study was developed in a public hospital for specialized and high complexity pediatric care located in the state of Espírito Santo.

\section{Data source}

In the development of instruments, were used articles on pressure injury selected from an integrative literature review and other materials, such as the protocol of the Ministry of Health, national and international clinical guidelines, textbooks, the Theory of Basic Human Needs by Wanda Horta ${ }^{(4)}$ and the report of the dressing committee of the institution under study.

\section{Data collection and organization}

The integrative review used the following guiding question: What are the nursing practices in the care of pediatric patients with pressure injuries? Databases used were: Latin American and Caribbean Health Sciences Literature (LILACS), Medical Literature Analysis and Retrieval System Online (MEDLINE) and Cumulative Index to Nursing and Allied Health Literature (CINAHL). The criteria adopted were complete articles in English, Portuguese and Spanish published in the period 2007-2017. The following Health Sciences Descriptors (DeCS) were used: "pressure ulcer", "pediatrics" and "assessment", and their respective terms in Portuguese and Spanish. After crossing the three descriptors, were found 71 articles, of which 26 met the inclusion criteria; two articles in LILACS, 22 in MEDLINE and two in CINAHL.

At a second moment, the content validation was performed by judges using the focus group technique, based on the theoretical references of Thofehrn ${ }^{(6)}$ and on the aspects of group interaction of Chizzoti ${ }^{(7)}$ and Freire, in which the group constitutes the core of the participatory pedagogical proposal(8).

This step was developed at the study hospital. The inclusion criteria to form the group of judges were to be a nurse with at least five years of experience in pediatric care. The judges received an invitation letter and after acceptance and signature of the Informed Consent form, the meetings were scheduled. Participants were 17 nurses working in different departments of the hospital.

Three focus groups were held with participation of five to six people. At the meeting, each participant received the material and after 15 minutes of reading, each item of the instrument was presented by the researcher. The nurses presented and discussed their ideas and accepted or refuted each item of the instrument. The meetings were recorded by iPhone $6 \mathrm{~S}$ plus mobile phone and transcribed in full.

\section{RESULTS}

The reading of the 26 articles and selected materials was organized into two management tools: an Nursing care systematization instrument for children with pressure injury based on Wanda Horta's Theory of Basic Human Needs ${ }^{(4)}$ and a Flowchart of pressure injury risk and prevention in pediatric patients.

The organization of these instruments was based on empirical evidence identified in the selected articles and materials. As the evidence predominantly brought biological issues, risk factors and signs of infection, the Nursing care systematization instrument for children with pressure injury addressed only the psychobiological needs ${ }^{(4)}$. Psychosocial and psycho-spiritual needs were not addressed, and the instrument was organized into three categories, namely: risk factors, psychobiological needs and signs of infection.

The organization of the flowchart followed the sequence of skin assessment and risk assessment correlated with prevention actions. The contents covered in the Flowchart of pressure injury 
risk and prevention were developed into three broad categories, subdivided into subcategories: 1) Assessment of patients' skin upon admission; 2) Risk assessment using the Braden Q Scale; 3) Preventive nursing care according to risk assessment. The category 3 included the following subcategories: nursing care in moisture control; prevention of PI in the occipital region; patient repositioning; protective covering; and the use of pressure redistribution surfaces.

The nursing prevention care according to risk assessment related to the three categories are: moisture management of patient's bed; prevention of $\mathrm{PI}$ in the occipital region; protective covering of injuries; patient repositioning in bed; and the use of pressure redistribution surfaces.

Regarding the characterization of the 17 judges, three professionals were part of the Dressing Committee of the study Hospital, six worked in the Pediatric Intensive Care Unit, two in the Outpatient Unit, one in the Hospital Infection Control
Commission, seven in the pediatric ward and one in the surgical ward. The longest working time as a nurse was 30 years, with an average of 13.4 years and the longest working time as a nurse in the study hospital was 25 years, with an average of 5.3 years. All professionals have specialization courses in different areas.

The Nursing care systematization instrument for children with pressure injury (Chart 1) and the Flowchart of pressure injury risk and prevention in pediatric patients (Figure 1) were validated by $100 \%$ of nurses. All professionals considered the tools were appropriate in relation to the content presented and easy to read because they highlight the specific nursing care.

After the validation meetings, the instrument was rebuilt according to nurses' suggestions. At the last meeting after the reading, the new material was opened for discussion and suggestions and there were no new modifications. The instrument was approved with $100 \%$ consensus of participants.

Chart 1 - Nursing care systematization instrument for children with pressure injury, Vitória, Espírito Santo, Brazil, 2018

\section{RISK FACTORS}

( ) ICU hospitalization ( ) Immobility ( ) Decreased sensory perception ( ) Hyperthermia ( ) Edema ( ) Malnutrition ( ) Obesity ( ) Hypoalbuminemia ( ) Anemia ( ) Moisture exposure ( ) Diarrhea ( ) Urge urinary incontinence ( ) Excessive sweating ( ) Exposure to wound exudate

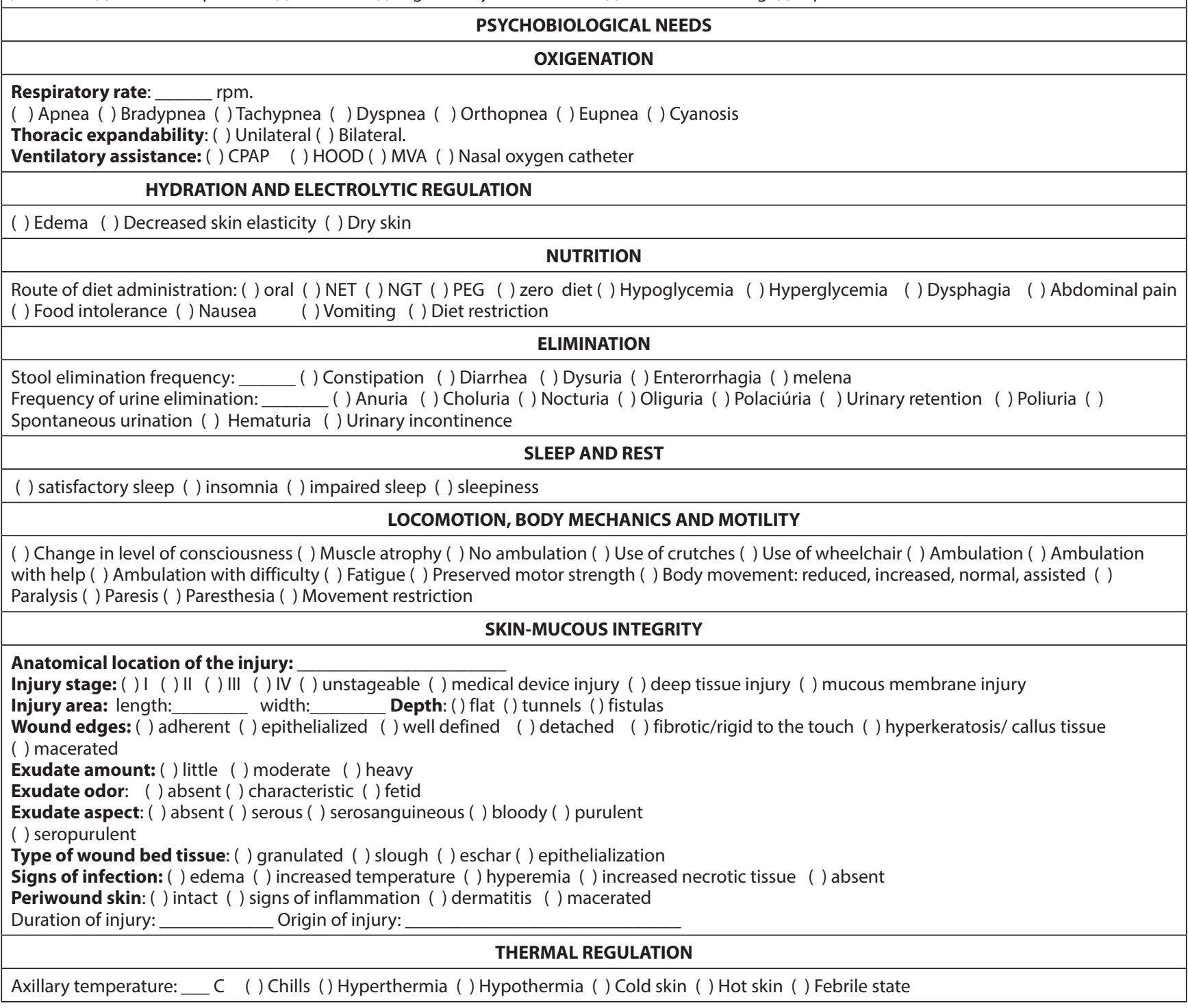




\section{NEUROLOGICAL REGULATION}

( ) Alteration in reflexes ( ) Mental confusion ( ) Convulsive crisis ( ) Delirium ( ) Disorientation

( ) Normal motor strength Level of consciousness:_ ( ) Paresis ( ) Paresthesia

\begin{tabular}{|c|c|c|c|}
\hline \multicolumn{4}{|c|}{ PAIN PERCEPTION } \\
\hline \multirow{2}{*}{ Behaviour } & \multicolumn{3}{|c|}{ Scale } \\
\hline & 0 & 1 & 2 \\
\hline Face & No particular expression or smile & Occasional grimace or frown & $\begin{array}{l}\text { Frenquent to constant quivering chin } \\
\text { clenched jow }\end{array}$ \\
\hline Legs & Normal position or relaxed & Uneasy, restless, tense & Kicking or legs drawn up \\
\hline Activity & $\begin{array}{l}\text { Lying quietly, normal position, moves } \\
\text { easily }\end{array}$ & Squirming, shifting, back and forth, tense & Arched, rigid or jerking \\
\hline Cry & No cry (awake or asleep) & $\begin{array}{l}\text { Moans or whimpers; occasional } \\
\text { complaint }\end{array}$ & $\begin{array}{l}\text { Crying steadily, screams, sobs, } \\
\text { frequent complaints }\end{array}$ \\
\hline Consolability & Content, relaxed & $\begin{array}{l}\text { Reassured by touching, hugging or being } \\
\text { talked to, distractible }\end{array}$ & Difficult to console or comfort \\
\hline
\end{tabular}

FLACC SCALE SCORE:

The child or adolescent must be uncovered, sleeping or awake. Observe the patient for 1 to 5 minutes to identify characteristics related to five categories. $0=$ no pain; 1 to $3=$ mild pain; 4 to $6=$ moderate pain; and 7 to $10=$ severe pain. Record in the electronic medical record. If pain is identified, discuss with the team what action to take.

\section{BASIC HUMAN NEEDS OF VASCULAR REGULATION}

( ) Normocardia ( ) Bradycardia ( ) Tachycardia ( ) Heart rate: ( ) Regular ( ) Irregular ( ) Arrhythmia ( ) Presence of murmurs, cyanosis, ecchymosis, bruising, hematuria, bleeding. Specify:___ ( ) Pulse type: ( ) Normal ( ) Strong/full ( ) Weak/fine ( ) Irregular

\section{SIGNS OF INFECTION}

( ) Slough granulation tissue ( ) Bad smell ( ) Increased pain in injury

( ) Increased wound drainage and changes in wound characteristics (recurrence of blood on drainage, purulent feature);

( ) Greater amount of necrotic tissue in wound bed;

( ) Appearance of pockets or necrosis in wound bed;

( ) No signs of healing after two weeks of appropriate treatment.

\section{HUMAN THERAPEUTIC NEEDS}

Injury cleaning: ( ) saline solution () distilled water ( ) PHMB

Dressing used: ( ) hydrogel ( ) polyurethane foam ( ) non sterile film ( ) alginate ( ) alginate with silver ( ) hydrocolloid others:

Recommendations on dressing change:

Source: Instrument adapted from Horta (1979) by Rodrigues; Prado; Bringuente (2018).

\section{DISCUSSION}

In the systematization of care for children with pressure injuries, management tools are considered powerful for care management and provision. This quality is attributed to various dimensions of care, which have the purpose to achieve greater benefits and patient safety. The World Health Organization has defined patient safety as the risk reduction of unnecessary harm to the minimum acceptable during health care $^{(9-10)}$.

Aimed at the prevention and reduction of the incidence of adverse events in all health facilities in the national territory, the National Patient Safety Program publishes several protocols, including those of pressure injuries, and has instituted the compulsory monthly notification of health care-associated adverse events ${ }^{(11)}$.

Several management tools can contribute to the management and quality process. Among them, the flowchart is a beneficial instrument to represent the sequence of steps followed in a process through graphic symbols, in order to improve the work process understanding by seeking the simplest, safest and most practical way to perform $\mathrm{it}^{(12)}$.

In this context, another important instrument for care management is the nursing process. It contributes to nurses' administration and management, human resource organization, and selection of work means and instruments that contribute to care planning ${ }^{(13-14)}$.

The phenomenon of pressure injury has been widely studied in adults, but research in children is less frequent. The extent of this health problem in the pediatric population is unknown, despite the importance of understanding the incidence and prevalence to assess the prevention effectiveness, resource requirements and resource allocation in this group. As the few prevalence publications vary widely, it is difficult to make evidence-based statements in relation to the frequency in pediatric populations ${ }^{(15-18)}$. However, more recent research shows that pediatric patients in all age groups are also at risk of developing pressure injuries ${ }^{(19)}$.

In Brazil, the development of technology has changed the profile of patients in the hospital setting. The higher survival rates in childhood brought a higher risk of pressure injury associated with therapeutic measures and higher complexity of care. With the phenomenon, also emerged a specific group of patients, that of children with special health needs. These children have or are at greater risk of chronic, developmental, behavioral or emotional physical conditions (CRIANES) ${ }^{(20)}$.

In addition, skin injuries are common comorbidities in critically ill hospitalized patients, who are at higher risk of PI due to prolonged bed stay ${ }^{(2)}$. 


\section{PRESSURE INJURY \\ RISK CLASSIFICATION AND PREVENTION IN PEDIATRIC PATIENTS}

Pressure Injury is a harm to the skin and/or underlying soft tissue, usually over a bony prominence or related to the use of a medical device or other artifact. The injury may present on intact skin or as an open ulcer and can be painful. The injury is a result of intense and/or prolonged pressure in combination with shear. The tolerance of soft tissue to pressure and shear may also be affected by microclimate, nutrition, perfusion, comorbidities and the condition of the tissue.

\section{NURSING ASSESSMENT}

PERFORM SKIN AND RISK ASSESSMENT THROUGH BRADEN Q SCALE WITHIN FIRST 24 HOURS AFTER ADMISSION

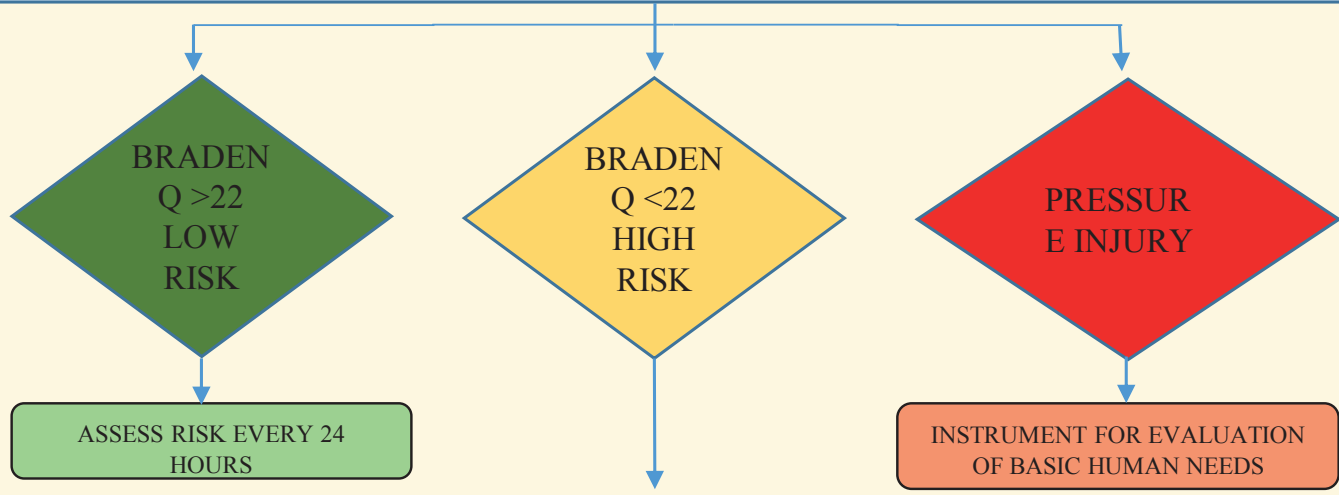

\section{NURSING CARE}

Moisture

$\checkmark \quad$ Use moisturizer after bath at least once a day

$\checkmark \quad$ Consider barrier cream in patients with incontinence,

excessive sweating or exposed to wound exudate

Repositioning

$\checkmark \quad$ Do not massage areas of prominent bone or hyperemia

Prevention of occipital PI

$\checkmark \quad$ Do not use ring or hoop shaped devices

$\checkmark \quad$ Perform head movements at regular intervals

$\checkmark \quad$ Repositioning every 2 hours

$\checkmark \quad$ Use slide sheets for transfer and mobilization of patients

$\checkmark \quad$ Keep headboard up to $30^{\circ}$

$\checkmark \quad$ Use pads under bony prominences

$\checkmark \quad$ Use a cushion or pillow below the legs to lift the heels

Pressure redistribution surface

Protective covering

$\checkmark \quad$ Transparent film on bony prominences

$\checkmark \quad$ Use pyramidal mattress

RISK FACTORS: ICU hospitalization; immobility; decreased sensory perception; hyperthermia; edema; moisture exposure: diarrhea, urinary incontinence, excessive sweating, exposure to wound exudate; malnutrition; obesity; hypoalbuminemia and anemia.

BRADEN Q SCALE FOR PRESSURE INJURY ASSESSMENT IN CHILDREN

\begin{tabular}{|lllll|}
\hline MOBILITY & 1. Completely immobile & 2. Very limited & 3. Slightly limited & 4. No limitation \\
\hline ACTIVITY & 1. Bedridden & $\begin{array}{l}\text { 2. Restricted to } \\
\text { bedside }\end{array}$ & $\begin{array}{l}\text { 3. Occasional } \\
\text { ambulation }\end{array}$ & $\begin{array}{l}\text { 4. Children too young to walk } \\
\text { and/or walk often }\end{array}$ \\
\hline $\begin{array}{l}\text { SENSORY } \\
\text { PERCEPTION }\end{array}$ & 1. Completely limited & 2. Very limited & 3. Slightly limited & 4. No limitation \\
\hline MOISTURE & 1. Constant moisture & 2. Frequent moisture & $\begin{array}{l}\text { 3. Occasional } \\
\text { moisture }\end{array}$ & 4. Rare moisture \\
\hline $\begin{array}{l}\text { FRICTION AND } \\
\text { SHEAR }\end{array}$ & 1. Important problem & 2. Problem & 3. Potential problem & 4. No apparent problem \\
\hline NUTRITION & 1. Very poor & 2. Inappropriate & 3. Appropriate & 4. Excellent \\
\hline $\begin{array}{l}\text { PERFUSION AND } \\
\text { OXYGENATION }\end{array}$ & 1.Extremely compromised & 2. Compromised & 3. Appropriate & 4. Excellent \\
\hline
\end{tabular}

Variation 7 - 28 points. Score 28: No risk of pressure injury. Score 7: maximum risk. Score less than 22 means high risk. Score greater than or equal to 22 means low risk.

Figure 1 - Flowchart of pressure injury risk and prevention in pediatric patients, Vitória, Espírito Santo, Brazil, 2018 
The recognition of injury in this population should not be neglected as it harms children's quality of life and causes pain and suffering due to negative psychosocial implications. Some complications cause alopecia, others, such as infection, increase the length of hospital stay, morbidity, workload of health professionals and the cost of hospital treatment ${ }^{(16,21-22)}$.

Compared to the adult population, children's anatomical and physiological characteristics modify the risk and manifestation of pressure injuries. The accelerated growth and development, the functional immaturity of various organs and systems, biological inequalities, and the more frequent and rapid manifestation of electrolyte disturbances at different stages of maturity, put children in a vulnerable condition ${ }^{(19,23)}$.

The susceptibility to pressure injuries can be assessed by riskdetermining instruments that can guide, direct, and optimize human and material resources for injury prevention, and reduce the workload of professionals and treatment costs. The early risk identification should be directly linked to a prevention plan ${ }^{(24)}$. The NPUAP recommends the assessment every eight hours, as children may develop PI within two hours, depending on their severity and catabolic conditions ${ }^{(2)}$.

Preventive care according to risk assessment is indispensable for these patients, and includes the use of the Braden Q scale, care related to moisture management of patients' bed, protective covering of injury, patient repositioning in bed, the use of pressure redistribution surface and skin hydration ${ }^{(11)}$.

Regarding the Nursing care systematization instrument for children with $\mathrm{Pl}$, the early detection of indicators listed in this instrument helps nurses to adopt preventive measures and choose the best treatment for these injuries ${ }^{(24-25)}$. In the instrument validation, some empirical indicators were identified as relevant for the assessment: severity, therapeutic procedures, use of vasoactive drugs, immobility in bed, connection of specific devices, long periods of hospitalization ${ }^{(24-25)}$, skin exposure to moisture, hypoalbuminemia identification ${ }^{(26)}$ and investigation of clinical signs of malnutrition, as malnourished patients are twice as likely to have skin injuries ${ }^{(11,26)}$.

In pressure injury, skin-mucous assessment demands critical thinking and clinical reasoning from nurses, since these are the basis for performing the evaluation. Wound classification and anatomical location establish a common language for the evolution of healing and help to promote clinical follow-up, thereby allowing a better judgment of the treatment implemented $(9,11,15,27)$.

The aim of pressure injury staging is to describe tissue, visual or palpable wound loss, which is classified to indicate the extent of tissue damage and update the nomenclature of stages of the classification system ${ }^{(11,28)}$. Monitoring includes length, width and depth and the staging of tissue injury in the assessment, because, in addition to recording the depth, there is control of the tissues involved in the pressure injury ${ }^{(27)}$. The size, type and amount of tissue and exudate present in the wound bed are indicators of healing and show if clinical care and topical therapy are achieving the proposed objective. Observation of wound edges and periwound skin are included in the instrument ${ }^{(2,28)}$.

Ischemic effects are possible risks of increased body temperature due to resistance to friction and will create weak layers of stratum corneum. The inclusion of body temperature control is recommended in all skin assessments ${ }^{(28-30)}$, i.e., for all patients.

As pain is an event present in children with pressure injury, a validated scale should be used in skin assessment for a better diagnosis, monitoring and treatment. Evaluation should be documented and accompanied by a clinically sensible and rigorous approach ${ }^{(28)}$.

Proper and appropriate wound management is a challenge aimed at healing the wound. The choice of a dressing should be balanced, well documented and regularly evaluated ${ }^{(9,30)}$. Through signs of infection, nurses can detect complications early and adjust the care plan. Infection increases the inflammatory phase of healing, causes tissue destruction, slows collagen synthesis and can lead to septicemia ${ }^{(28-29)}$.

\section{Study limitations}

The limitations of this study were the need to evaluate the applicability of the tools after implementation in the service and the fact that all judges belong to the same institution. We recommend the validation considering professionals from different organizations.

\section{Contributions to the area}

The instrument will support nurses' decision-making regarding children with pressure injury and will allow a careful and individualized assessment of each patient, therefore, filling the gap of an instrument for the holistic evaluation of clients. The tools will be integrated into the electronic medical record system of the hospital in order to contribute to documentation of care provided to children with pressure injuries.

\section{FINAL CONSIDERATIONS}

In this study, were developed two management tools. The first was the Nursing care systematization instrument for children with pressure injury with three parts: a) risk factors; b) Psychobiological Basic Human Needs; c) signs of wound infection. The second was the Flowchart of pressure injury risk and prevention in pediatric patients with three categories: a) risk factors; b) Braden Q scale; c) nursing care. The management tools enabled the synthesis of nursing assessment, the outline of guidelines regarding risks, and the guidance of nursing care in the face of these risks based on basic human needs.

\section{REFERENCES}

1. Vocci MC. Guia de consulta rápida: informativo para supervisão e cuidado com a pele mucosa e avaliação de risco de lesões por pressão nos pacientes pediátricos. 2016.

2. National Pressure Ulcer Advisory Panel, European Pressure Ulcer Advisory Panel, Pan Pacific Pressure Injury Aliance. Prevention and Treatment of Pressure Ulcers: Clinical Practice Guideline. Washington:NPUAP/EPAUAP/PPPIA; 2014. 
3. Stuque AG. Proposição de protocolo de prevenção para úlcera por pressão para pacientes clínicos no contexto hospitalar [Dissertação]. Escola de Enfermagem de Ribeirão Preto: São Paulo. Ribeirão Preto; 2016.

4. Horta WA. Processo de Enfermagem. São Paulo: EPU; 1979.

5. Fawcett J. Criteria for Evaluation of Theory. Nurs Sci Q. 2005;18(2):131-5. doi: /10.1177/0894318405274823

6. Thofehrn MB, Montesinos MJL, Porto AR, Amestoy SC, Arrieira ICO, Mikla M. Grupo focal: una técnica de recogida de datos en investigaciones cualitativas. Index Enferm. 2013;22 (1). doi: 10.4321/S1132-12962013000100016

7. Chizzotti A. Pesquisa qualitativa em Ciências Humanas e Sociais. Petrópolis: Vozes, 2006.

8. Freire P. Pedagogia do oprimido. Rio de Janeiro: Paz e Terra, 2013.

9. Agency For Healthcare Research And Quality's (AHRQ). Guide to Clinical Preventive Services: Recommendations of the U.S. Preventive Services Task Force. 2012.

10. Vasconcelos J MB, Caliri MHL. Ações de enfermagem antes e após um protocolo de prevenção de lesões por pressão em terapia intensiva. Esc Anna Nery. 2017;21(1). doi: 10.5935/1414-8145.20170001

11. Ministério da Saúde (BR). Secretaria de atenção à saúde. Protocolo para prevenção de úlcera por pressão. 2013.

12. Peinado J, Graeml AR. Administração da produção: operações industriais e de serviços. Curitiba: Unicenp; 2007.

13. Benedet AS, Gelbcke FL, Amante LN, Padilha MAS, Pires DP. Processo de Enfermagem: instrumento da Sistematização da Assistência de enfermagem na percepção dos enfermeiros. Rev Pesqui Cuid Fund. 2016;8(3):4780-88. doi: 10.9789/2175-5361.rpcfo.v8.4237

14. Soares MI, Resck ZMR, Camelo SHH, Terra FS. Gerenciamento de recursos humanos e sua interface na sistematização da assistência de enfermagem. Enfermería Global. 2016;15(2):341-75. doi: 10.6018/eglobal.15.2.214711

15. García-Molina P, Balaguer-López E, Torra-I-Bou JE, Alvarez-Ordiales A, Quesada-Ramos C, Verdú-soriano A. A prospective, longitudinal study to assess use of continuous and reactive low-pressure mattresses to reduce pressure ulcer incidence in a pediatric intensive care unit. Ostomy Wound Manage [Internet]. 2012[cited 2019 Jan 20];58(7):32-9. Available from: https://pubmed.ncbi.nlm.nih.gov/22798352/

16. Davies K, Yesudian PD. Pressure Alopecia. Int J Trichology. 2012;4(2):64-8. doi: 10.4103/0974-7753.96901

17. Bernabe KQ. Pressure ulcers in the pediatric patient. Curr Opin Pediatr. 2012;24(3):352-6. doi: 10.1097/MOP.0b013e32835334a0

18. Vangilder C, Lachenbruch C, Algrim-boyle C, Meyev RS. The International Pressure Ulcer Prevalence ${ }^{\text {TM }}$ Survey: 2006-2015: a 10-year pressure injury prevalence and demographic trend analysis by care setting. J Wound Ostomy Continence Nurs. 2017;44(1):20-28. doi: 10.1097/ WON.0000000000000292

19. Peterson J, Adlard K, Walti BI, Hayakawa J, McClean E, Feidner SC. Clinical nurse specialist collaboration to recognize, prevent, and treat pediatric pressure ulcers. Clin Nurse Spec. 2015;29(5):276-82. doi: 10.1097/NUR.0000000000000135

20. Neves ET, Cabral IE. Cuidar de crianças com necessidades especiais de saúde: desafios para as famílias e enfermagem pediátrica. Rev Eletrônica Enferm [Internet]. 2009[cited 2019 Jan 20];11(3):527-38. Available from: http://www.fen.ufg.br/revista/v11/n3/v11n3a09.htm

21. Maia ACAR, Pellegrino DMS, Blanes L, DINI GM, Ferreira LM. Tradução para a língua portuguesa e validação da escala de Braden $Q$ para avaliar o risco de úlcera por pressão em crianças. Rev Paul Pediatr. 2011;29(3):405-14. doi: 10.1590/S0103-05822011000300016

22. Visscher M, King A, Nie AM, Schaffer P, Taylor T, Pruitt D, et al. A quality-improvement collaborative project to reduce pressure ulcers in PICUs. Pediatrics. 2013;131(6):e1950-60. doi: 10.1542/peds.2012-1626

23. Williams K, Thomson D, Seto I, Contopoulos-Ioannidis DG, loannidis JP, Curtis S, et al. Standard 6: age groups for pediatric trials. Pediatrics. 2012;129(Suppl-3):S153-60. doi: 10.1542/peds.2012-0055।

24. Borghardt AT, Prado TN, Araújo TM, Rogenski NMB, Bringuente MEO. Evaluation of the pressure ulcers risk scales with critically ill patients: a prospective cohort study. Rev Latino-Am Enfermagem. 2015;23(1):28-35. doi: 10.1590/0104-1169.0144.2521

25. Schindler CA, Mikhailov TA, Kuhn, EM, Christopher J, Conway P, Ridling D, et al. Protecting fragile skin: nursing interventions to decrease development of pressure ulcers in pediatric intensive care. Am J Crit Care. 2011;20(1):26-34. doi: 10.4037/ajcc2011754

26. Curley MA, Quigley SM, Lin M. Pressure ulcers in pediatric intensive care: incidence and associated factors. Pediatr Crit Care Med. 2003;4(3):284-90. doi: 10.1097/01.PCC.0000075559.55920.36

27. Malagutti W, Kakihara CT. Curativos, ostomias e dermatologia: uma abordagem multiprofissional. São Paulo: Martinari, 2014.

28. Walker R, Aitken L. Pressure injury prevention pilot study: a follow-up. Qld Nurse [Internet]. 2015[cited 2019 Jan 20];34(3):33. Available from: https://pubmed.ncbi.nlm.nih.gov/26197681/

29. Iron G. Feridas: novas abordagens, manejo clínico e atlas em cores. Rio de Janeiro: Guanabara Koogan, 2012.

30. Schlüer AB, Schols JM, Halfens RJ. Risk and associated factors of pressure ulcers in hospitalized children over 1 year of age. J Spec Pediatr Nurs. 2014;19(1):80-9. doi: 10.1111/jspn.12055 